\title{
A CASE STUDY WORKSHOP AND A PROBLEM-SOLVING APPROACH TO TECHNICAL COMMUNICATION
}

\author{
ANNe Parker
}

\begin{abstract}
This article describes a problem-solving approach to a first-year technical communication course. By showing the kinship between them, such an approach emphasizes that both engineering design and communication use a similar strategy to reach a "best" solution to a problem: classify, analyze, test and solve (C.A.T.S.). Coupled with the workshop format and, in particular, with a case study, this approach provides a professional context for the engineering student so that, finally, students can become more proficient problem-solvers and communicators.
\end{abstract}

When the Faculty of Engineering at the University of Manitoba decided to include a technical communication course in the first-year curriculum, they looked at ways to make the structure of the course similar to that of the lecture-lab format of the other engineering courses. Their solution was the workshop which, like the lab, was to give students the opportunity to apply the theory taught in the lecture; to give students, in other words, practical experience and not just information.

This was the format already in place in 1982 when the compulsory first-year course was introduced. In both the fall and spring terms, the six sections of the course were to each receive one lecture hour per week and two workshop hours per week, each workshop to have an enrollment of roughly 30 students. Ostensibly, the goal of this format was to combine instructional methods and thereby increase the potential for learning (Engin and Engin 359).

Besides the "technical communication instructor," an academic appointment, two or three "teaching assistants" were hired to help staff the workshops. But the educational background and teaching experience of 
these assistants varied. For example, at least one was a graduate student in English, since this person helped with the marking. The others were usually graduate students in an engineering department, and both their teaching experience and their knowledge of the communication field were often limited.

As a result, for at least the first two years after the course was introduced, these workshops tended to be "make work" time in which students labored on exercises and assignments under the workshop leader's watchful eye. Like so many other engineering labs, then, these workshops were "almost as sterile and remote from real practice as [were] our problem assignments" (Flammer 372). But this kind of format at least allowed the assistants with a limited background to feel more comfortable with the course.

In the last few years, however, the workshops have developed into the kind of labs which would fulfill the faculty's original intent and which would help students recognize communication as part of the engineer's professional activity. Moreover, this development has helped me, as the technical communication instructor/co-ordinator, to structure the labs so that all workshop leaders, regardless of background and experience, can teach the material and help the students become better technical communicators.

\section{The Problem-Solving Approach to Technical Communication}

In large part, this is the result of the development of an approach designed to connect the engineering method students are being introduced to in their other courses, as Winkler (1983) and Goulter note, and the principles of writing and speaking to be taught in the technical communication course. Based on the accepted precept that engineers are problemsolvers, this problem-solving approach to technical communication, following the Mathes and Stevenson model, emphasizes that communication in the engineering context comes about as a direct result of an engineering problem or task (31).

Moreover, in the search for a "best" solution to a problem, as Woods et al (1975: 238) define problem-solving, the same strategies used by the engineer to solve an engineering problem can be applied to communication; that is, the same steps used in engineering design are the same steps used in communicating the results of the engineering activity, as seen in Figure 1. 
Many researchers, including those who introduce engineering design to students, like Krick and Beakley et al, and those who study engineering problem-solving, like Woods et al (1975 and 1983), outline similar steps. And, of course, scholars in the field of technical communication have also seen this connection between communication and problem-solving; for example, Barton and Barton, Dunkle and Pahnos, Flower, Maki and Schilling, Moran, Robinson, Trzyna and Batschelet, and Winkler.

But what makes this approach so workable in a first-year engineering course is its emphasis on problem-solving as part of the entire engineering activity, and its concomitant emphasis on a methodology, a clear-cut "means of accomplishing writing tasks" (Blyler 5) but without what Winkler calls "lock-up procedures" which nullify its value as a recursive process (1983: 119). As such, the students come to see communication as an important part of an engineer's professional life, and they learn to become more proficient problem-solvers and communicators.

\section{The Technical Communication Workshop and the Problem-Solving Approach}

The workshop format, as opposed to the more "prescriptive" (Sides 65) and "dehumanized" (Albin and Flammer 406) lecture format, provides the flexibility needed to accomplish these goals (Felder and Silverman 678). In the lecture, students may well have merely transcribed what the instructor has written on the board or flashed on the overhead projector, a tendency noted by Woods et al (1975: 241). But, if students have in fact lapsed into passive learning, it becomes less "harmful" when the course also includes another instructional mode, the workshop, which combines teaching, class discussion and small group work.

In the workshop, students are reminded of the fundamental principles of the topic at hand: they work through a problem which illustrates a particular aspect of engineering and communication problem-solving, as Robinson suggests (1983: 315); they contribute to the discussion of these principles, as a class and in small groups (in any class we can have 6-10 groups, depending on enrollments); and they receive practice in implementing the problem-solving process that will help to lead them to a solution.

Therefore, the problem-solving approach structures the workshop activities and enhances a student's problem-solving and communication abilities. The workshop format, for its part, encourages active (as opposed 
to passive) learning, strengthens the perceived usefulness of the problemsolving approach and, as Robinson (1983) states, does so in a nonthreatening, more active way (314).

One workshop which exemplifies this flexibility is the "Case Study Workshop," which actually extends over two class hours. After the lectures on the problem-solving approach, audience analysis, purpose formulation and organizational (or rhetorical) patterns-that is, the content to be covered in these and successive labs-students receive a handout detailing a "real" engineering problem. They can then do as much or as little preparation for the workshops as they choose. In this way, whatever has been covered in the lectures will be reinforced and applied in the workshops.

\section{The Case Study Workshops}

The case itself, developed by Dr. M. Britton of the Department of Agricultural Engineering, is one of several I have successfully used over the past few years. It first asks students to grapple with the technical issue, the problem of transporting prairie grain. This represents a lively, on-going debate and, at times, a controversial issue on the Canadian prairies. So, it is relevant and current for most first-year engineering students. Moreover, this particular case study does indeed "illustrate how communication is part of the problem-solving process" (Brockmann 11); the writer is both technical problem-solver and rhetorical problem-solver (Couture, Goldstein and Brockmann 25); and the problem is real in terms of the issues involved and in terms of its application to the students' future professional lives (Flammer 372; Wales, Nardi and Stager 684-685).

Following is an excerpt of the essential background information students need to solve the problem:

We all know Canada is a major grain exporter. In the 1986-87 crop year, we moved approximately 36 million tonnes of grain from the prairies, where it was produced, to coastal terminals, where it was loaded onto ships for sale overseas. But the problem with this system is one of cost.

On the one hand, Canadian farmers are concerned that shipping rates are too high and do not allow them to compete as vigorously as they believe they should. On the other hand, the rail companies argue that the payment they receive does not permit them to show the profit they believe that they deserve. The Western Grain Tariff Agreement sets a freight rate for bulk grain at about \$6 per tonne (averaged over the country), but the rail companies claim a breakeven point of $\$ 10$ per tonne. 
The system used to move grain, a system which has a long history in western Canada, is much the same as the one used at the turn of the century. Then, as now, elevators, grain trains and shipping terminals are the basic units.

Under the current system, the producers truck their grain to elevators which are located on rail lines. Typically, a small community has developed at each of these sites. The rail lines bring grain cars to the elevators, leave them in place for some time to be loaded (from one to four days), reassemble a "grain train" from the loaded cars and move them to a central point where a transnational train can be assembled. Once the final unit has been assembled, it is moved to a terminal for eventual overseas shipment.

Historically, elevators were located from 10 to $15 \mathrm{~km}$ apart, a distance which represented a maximum one-day round trip with a team and wagon. As well, elevators were built with a number of storage bins; the capacity of one bin equalled the capacity of one box car or about $\mathbf{5 0}$ tonnes. This system meant, then, that enough grain of a given quality could be stored to justify spotting rail cars. Although today's elevators are larger and have a greater capacity for the rapid movement of grain, they are essentially no different than their turn-of-the-century predecessors.

Grain cars themselves have changed from the traditional "box car," which has a capacity of 50 to 60 tonnes, to hopper cars, which have a capacity of 90 to 100 tonnes. In addition to this greater capacity, hopper cars are also much simpler to fill and empty. Unfortunately, some regional rail lines cannot handle the extra load imposed by the hopper cars (the Churchill line is an excellent example).

Because the students are first-year and lack the requisite technical background Sides would consider important for a less structured tutorial (68), this case study offers three solutions, all technically feasible (even though research is still in progress): New Inland Terminals, a transCanada Grain Pipeline, and Processing the Grain before Shipment. Sufficient detail has been included for each of these alternatives so that students can assess them.

\section{Case Study Workshop I: Technical Problem-Solving}

In the first case study workshop, the students begin as a class to classify and analyze. The students themselves do the work and the instructor 
acts as a resource person or referee, as the situation demands. They try to define the problem, namely, what must be solved. Most students quickly see that cost is a problem primarily because the case study does mention this specifically.

At this point, however, we can also begin to break the problem down and probe it further: why, for example, are costs so high? Asking students to look at causes for something forces them to go beyond easy answers, to go beyond what Sides calls their "either-or thinking" (68). In this real-life problem, many factors have contributed to the problem of cost; for example, outdated technology, the distances and times involved, the nature of the product itself. If students do introduce the notion that "wheat is $14 \%$ protein and $86 \%$ politics," we can then turn the discussion to why, if the situation were a purely political one, is engineering input necessary? As Dr. Britton points out in the case study: "Because this debate involves physical systems which contribute both to the problem and to the solution, engineering input is vital." In this important way, the students start to appreciate the context in which an engineer usually works.

Students then go into small groups of 3 or 4 where they first establish for themselves the technical issues involved and any specifications a grain delivery system must meet if it is to be viable. When they feel satisfied that this part of the process is fairly complete, the group turns to the second problem-solving activity, analysis, where they study the three alternatives. If they wish, they can introduce new options or combinations of alternatives, including doing nothing to change the current system. Usually, however, as Allen has found, successful groups tend to look at only two alternatives at a time (76) and seldom do they generate new options until necessary (77). Finally, the group must choose a "working solution," a particular alternative (or combination of alternatives) which they can test.

Clearly, these groups cannot create their own "prototype" of the working solution, but they can test it according to three very important questions:

(1) does the working solution solve the problem (as the group has defined it)?

(2) does it satisfy the specifications (as defined)?

(3) does the solution create any technical, social or economic problems?

Once the groups have worked through this part of the workshop, we can then as a class discuss each group's analysis and further test its chosen alternative. 
In sum, this first case study workshop allows the class to focus on the "real world" of engineering problems, where problems are not always neatly formulated and where other, less technical factors can cloud the issues. We also have the freedom to move beyond the engineering "artifact," the technology, and emphasize the impact engineers have on the world around them. In Koen's words, we can move closer to that elusive "art of engineering" (155).

\section{Case Study Workshop II: Communication Problem-Solving}

Having studied these technical issues, having been introduced to "realworld" engineering and having seen the importance of the problem-solving heuristic in engineering, the class moves to a consideration of the next level, communicating the solution to someone else. In the workshop, we begin by asking who would be interested in a document proposing a solution to the problem. The possibilities seem endless and, as we put these possibilities on the board, students realize how far-reaching an engineering decision and an engineering document can be.

Then, following the advice of Couture, Goldstein and Brockmann that the case use a "clearly defined, independent writing assignment" (30), we now assign students a short report which they are to write and submit on their own. Our goal in these two case study workshops is to have students practice problem-solving skills and gain experience in a particular writing task, audience analysis, so the group work helps students to define the problem and tailor their individual reports to this particular audience. It is a skill they can apply to the other technical communication assignments or indeed to any engineering document. This approach gives these first-year students the guidance they need at this stage while, at the same time, it helps to reinforce the communication problem-solving process.

In this instance each student assumes a particular role (a consulting engineer whose firm specializes in transport and agricultural engineering); follows a particular format (problem-solution); and writes for a particular audience (the Manager of the rail company's prairie regional office; her team of economists and engineers; and the student's own boss in the consulting firm). The required short report, like many professional engineering documents, demands that students meet the assignment's specifications so that the audience can do its job of advising the head office and the government as to how to solve the problem (if at all). 
Once again, students form small groups of 3 or 4 , where they classify their assigned readers according to how these readers will use the document. Groups will also have to analyze their readers' technical levels, their educational levels, their attitudes to the subject, and any other variable students deem important.

Given this audience analysis, student groups, and later each student, must then decide what information must be included if the document is to meet this audience's informational needs. This selection of detail helps them to recognize the importance of including both what is relevant to the reader and what is necessary to support the proposed solution. Organizing this information into the required format and formulating a purpose statement can only be done once they have carefully analyzed their audience. Students who try to do these tasks too early inevitably discover the recursive nature of the process and, at times, the need for more "brainstorming."

Finally, the class as a whole shares what individual students and groups have determined. Here, as a final reinforcement, the instructor can emphasize the importance of careful, systematic audience analysis and the need to test any solution and any document according to the audience's informational needs. At this point, we can remind them as well that the problem-solving approach can help them to do this kind of analysis and testing, both before and after they write a draft of the document.

Students then write their individual reports in which they can adopt the group's view or they can argue their own point of view. In any case, students will be evaluated, not just on the basis of their writing style, but also on the basis of the report's tone (which must be adapted to the audience), the report's format and the report's statement of purpose. The information extracted from the case study must convince the reader that the solution proposed in the report is indeed the one to best suit C.N.'s needs.

\section{Conclusion}

Both case study workshops stress the "two hats" the engineer wears: that of the technical problem-solver and that of the communication problemsolver (Mathes and Stevenson 42). But in both instances the engineer can use the same strategies to solve the problem. Because the problem-solving approach is a methodology as well as a process, as Plants et al (22) point out, first-year engineering students can tackle the communication problem more easily and, in time, more successfully than they might have done using a more traditional "English" approach to writing. Coupled with the efficacy 
of this approach is the freedom the workshop offers: it encourages both discovery, as Valletta and Paoletti suggest a heuristic should (216), and cooperative efforts, as O'Keefe states an alternative classroom practice should (93); it makes students more aware of the demands they will face on the job; and, ultimately, it does so in a less prescriptive, less demanding way than the traditional lecture could do.

At last the technical communication workshop has indeed become more like a lab where ideas can be tested and problems solved. As a heuristic, a problem-solving approach to technical communication, especially when it is used in conjunction with a workshop format and the case study method, may well be one of those "better techniques for teaching the process of technical communication" that Kent argues for (251). 
FIGURE 1

Problem-Solving Steps in EngIneering

Design and Communication Design

\begin{tabular}{|c|c|c|}
\hline Procedure/Activity & Engineering Design & Communication Design \\
\hline C Classify & \multicolumn{2}{|c|}{$\begin{array}{l}\text { - problem definition } \\
\text { - gathering data } \\
\text { - "brainstorming" } \\
\qquad \begin{array}{l}\text { - audience analysis } \\
\text { - purpose formulation }\end{array}\end{array}$} \\
\hline A Analyze & \multicolumn{2}{|c|}{$\begin{array}{l}\text { - developing ideas/possible solutions } \\
\text { - looking at technical alternatives } \\
\text { - developing a working solution } \\
\qquad \begin{array}{c}\text { - looking at commun- } \\
\text { ication alternatives } \\
\text { (patterns, outlines) }\end{array}\end{array}$} \\
\hline $\mathbf{T}$ Test & \multicolumn{2}{|c|}{$\begin{array}{l}\text { - evaluating the working solution } \\
\text { - prototype } \mid \text { - draft version }\end{array}$} \\
\hline S Solve & \multicolumn{2}{|c|}{$\begin{array}{l}\text { - implementing the chosen } \\
\text { alternative/solution } \\
\text { - final engineering product } \\
\text { - final document }\end{array}$} \\
\hline
\end{tabular}




\section{REFERENCES}

1. Albin, Henry L and Gordon H. Flammer. "Motivation and the Lecture Method of Instruction." Engineering Education 64.6 (1974): 404-407.

2. Allen, Thomas J. "Studies of the Problem-Solving Process in Engineering Design." IEEE Transactions on Engineering Management EM-13 (1966):72-83.

3. Barton, Ben F. and Marthalee S. Barton. "The Case Method: Bridging the Gap between Engineering Student and Professional." Courses, Components, and Exercises in Technical Communication. Ed. Dwight W. Stevenson. Urbana: National Council of Teachers of English, 1981. 22-23.

4. Barton, Ben F. and Marthalee S. Barton. "Toward Teaching a New Engineering Professionalism: A Joint Instructional Effort in Technical Design and Communication." Technical and Professional Communication: Teaching in the Two-Year College, Four-Year College, Professional School. Ed. Thomas M. Sawyer. Ann Arbor:- Professional Communication Press, Inc., 1977. 119-128.

5. Beakley, G.C., D.L. Evans and J.B. Keats. Engineering: An Introduction to a Creative Profession. Sth edition. New York: Macmillan Publishing Company, 1986. Chapters 9 and 12.

6. Blyler, Nancy Roundy. "The Heuristics of Pedagogy: Approaches to Teaching Technical Writing." The Technical Writing Teacher 13.2 (1986): 101-111.

7. Brockmann, R. John. "What is a Case?" The Case Study Method in Technical Communication: Theory and Models. Ed. R. John Brockmann. The Association of Teachers of Technical Writing, 1984. 1-16.

8. Couture, Barbara, Jone Rymer Goldstein and R. John Brockmann. "Cases as Communication Problems for Writers: How Do They Differ?" The Case Method in Technical Communication: Theory and Models. Ed. R. John Brockmann. The Association of Teachers of Technical Writing, 1984. 25-32. 
9. Dunkle, Susan B. and David M. Pahnos. "Decision-Making and Problem-Solving: An Holistic Writing Assignment." Courses, Components, and Exercises in Technical Communication. Ed. Dwight W. Stevenson. Urbana: National Council of Teachers of English, 1981. 205-209.

10. Engin, Ann W. and Ali E. Engin. "The Lecture: Greater Effectiveness for a Familiar Method." Engineering Education 67.5 (1977): 358-362.

11. Felder, Richard M. and Linda K. Silverman. "Learning and Teaching Styles in Engineering Education." Engineering Education 78.7 (1988): 674-681.

12. Flammer, Gordon H. "The Case Study: Exercise in Simulation." Engineering Education 67.5 (1977): 372-373.

13. Flower, Linda S. "Communication Strategy in Professional Writing: Teaching a Rhetorical Case." Cousses, Components, and Exercises in Technical Communication. Ed. Dwight W. Stevenson. Urbana: National Council of Teachers of English, 1981. 33-46.

14. Flower, Linda S. Problem-Solving Strategies for Writing. Harcourt Brace Jovanovich, 1981.

15. Flower, Linda S. and John Hayes. "Problem-Solving Strategies and the Writing Process." College English 39.4 (1977): 449-461.

16. Goulter, I. and S. Simonovic. "The Need for Systems in First Year Engineering." Proceedings of the Sixth Canadian Conference on Engineering Education, Winnipeg, Canada, May 16-17, 1988. 422-440.

17. Kent, Thomas. "Schema Theory and Technical Communication." Joumal of Technical Writing and Communication 17.3 (1987): 243-252.

18. Koen, Billy Vaughn. "Toward a Definition of the Engineering Method." Engineering Education 75.3 (1984): 151-155.

19. Krick, Edward. An Introduction to Engineering: Methods, Concepts, and Issues. New York: John Wiley, 1976. Chapters 4-11. 
20. Maki, Peggy and Carol Schilling. Writing in Organizations: Purposes, Strategies, and Processes. McGraw-Hill Book Company, 1987.

21. Mathes, J.C. and Dwight W. Stevenson. Designing Technical Reports: Writing for Audiences in Organizations. Bobbs-Merrill, 1976.

22. Moran, Michael G. "A Problem-Solving Heuristic." Technical Communication 29.3 (1982): 38.

23. O'Keeffe, Anthony. "Teaching Technical Writing." Research in Technical Communication: A Bibliographic Sourcebook. Eds. Michael G. Moran and Debra Journet. Westport and London: Greenwood Press, 1985.

24. Plants, H.L., R.K. Dean, J.T. Sears, and W.S. Venable. "A Taxonomy of Problem-Solving Activities and Its Implications for Teaching." The Teaching of Elementary Problem Solving in Engineering and Related Fields. Ed. James L. Lubkin. Washington, D.C.: ASEE Monograph, 1980. 21-34.

25. Robinson, Patricia A. Fundamentals of Technical Writing. Boston: Houghton Mifflin, 1985.

26. Robinson, Patricia A. "Technical Writing Workshops: An Altemative to Lectures." Engineering Education 73.4 (1983): 314-315.

27. Sides, Charles H. "Comparing the Case Approach to Five Traditional Approaches to Teaching Technical Communication." The Case Method in Technical Communication: Theory and Models. Ed. R. John Brockmann. The Association of Teachers of Technical Writing, 1984. $65-70$.

28. Trzyna, Thomas and Margaret W. Batschelet. Writing for the Technical Professions. Belmont, California: Wadsworth Publishing Company, 1987.

29. Valletta, Clement Lo and Robert A. Paoletti. "A Structural Heuristic and Writing: Language and DNA upon a Blue Guitar." Joumal of Technical Writing and Communication 17.3 (1987): 215-229. 
30. Wales, Charles E., Anne H. Nardi, and Robert A. Stager. "Do Your Students Think, Or Do They Memorize?" Engineering Education 78.7 (1988): 682-688.

31. Winkler, Victoria M. "Creative Design and Rhetorical Inquiry: Report Writing Strategies." Proceedings of the 27th International Technical Communication Conference, Minneapolis, May 14-17, II, 1983. W89-W97.

32. Winkler, Victoria M. "The Role of Models in Technical and Scientific Writing." New Essays in Technical and Scientific Communication: Research, Theory, Practice. Eds. P.V. Anderson, R.J. Brockmann and C.R. Miller. Farmingdale, N.Y.: Baywood Publishing, Inc., 1983. 111-122.

33. Woods, Donald R. "Problem Solving and Chemical Engineering, 1981." Problem Solving 79. Eds. J.T. Sears, D.R. Woods and R.D. Noble. New York: American Institute of Chemical Engineers, 1983. 11-27.

34. Woods, Donald R. and Cameron M. Crowe. "Characteristics of Engineering Students in Their First Two Years." Engineering Education 74.5 (1984): 289-295.

35. Woods, Donald R., Cameron M. Crowe, Terrence W. Hoffman and Joseph D. Wright. "Major Challenges to Teaching Problem-Solving Skills." Engineering Education 70.3 (1979): 277-284.

36. Woods, D.R., J.D. Wright, T.W. Hoffman, R.K. Swartman and I.D. Doig. "Teaching Problem Solving Skills." Engineering Education 66.3 (1975): 238-243.

Dr. Anne Parker, an Assistant Professor in Electrical Engineering University of Manitoba, teaches technical communication to first-year engineering students. Her research interests include the importance of technical communication to engineering students, faculty and the profession. She has published articles in both literature and technical communication. 